\title{
МОНІТОРИНГ ОСНОВНИХ ЗАСОБІВ ІННОВАЦІЙНОГО ЗАБЕЗПЕЧЕННЯ У СФЕРІ ОХОРОНИ ЗДОРОВ'Я УКРАЇНИ У 2017 p.
}

\author{
Український центр наукової медичної інформації та патентно-ліцензійної роботи МОз України, \\ м. Київ, Україна
}

\begin{abstract}
Мета: провести моніторинг основних засобів інноваційного забезпечення у ссрері охорони здоров'я України у $2017 \mathrm{p}$

Матеріали і методи. Проаналізовано основні засоби інноваційного забезпечення у сфері охорони здоров'я України, розроблені у 2017 р. Застосовано методи експертної оцінки, статистичного, системного, структурнологічного та кластерного аналізу.

Результати. Ретроспективний аналіз основних засобів інноваційного забезпечення у сфері охорони здоров'я України у 2017 р. показав, що за даний період найбільше було розроблено методичних рекомендацій та інорормаційних листів установами МОЗ України - 83,74 \% та 80,95 \% відповідно. Установи-розробники найбільшу увагу приділяли проблемам «Фармакологія. Фармація. Клінічна фрармакологія і клінічна фрармація. Організація і управління фрармацією» та «Стоматологія». За вказаний період науковцями було запропоновано найменшу кількість як методичних рекомендацій, так й інформаційних листів за медичними напрямами «Медична генетика», «Судова медицина» та «Урологія».

Висновки. Для підвищення рівня здоров'я населення та покращення якості його медичного обслуговування необхідно розробляти більше засобів наукової комунікації з подальшим їх впровадженням у практичну діяльність закладів охорони здоров'я.
\end{abstract}

КЛЮчОВІ СЛОВА: моніторинг; охорона здоров'я; інноваційне забезпечення.

Успішне ресормування сфери охорони здоров'я України можливе лише за умов сталого інноваційного розвитку медичної науки. Підґрунтям підвищення медичної, соціальної та економічної ефрективності фрункціонування системи охорони здоров'я $є$ раціональне впровадження інноваційних технологій лікування, діагностики, профрілактики захворювань, вдосконалення менеджменту закладів охорони здоров'я [1, 3].

Інноваційні процеси у медичній галузі варто розглядати як пріоритетний напрямок розвитку медичної науки і практичної охорони здоров'я, а формування засобів наукової комунікації - як найважливішу складову цього процесу.

Для успішного здійснення інновацій у цілому та їх окремих етапів необхідно максимально забезпечити використання інсрормаційних джерел та комунікаційних засобів [4].

Важливу роль у підвищенні ефективності медичної допомоги населенню відіграють засоби наукової комунікації, які інформують спеціалістів про новітні досягнення медичної науки. Результати науководослідних робіт відображаються в методичних рекомендаціях (MP), інорормаційних листах (IЛ), доповідаються на наукових медичних форумах (МФ).

Мета роботи: провести моніторинг основних засобів інноваційного забезпечення у сфері охорони здоров'я України у 2017 р.
Матеріали і методи. Експертами Українського центру наукової медичної інфрормації та патентноліцензійної роботи МОЗ України (Укрмедпатентінформ) проаналізовано основні засоби інноваційного забезпечення у сфрері охорони здоров'я України, розроблені у 2017 р.: 123 методичні рекомендації та 399 інформаційних листів.

Застосовано методи експертної оцінки, статистичного, системного, структурно-логічного та кластерного аналізу.

Результати дослідження та їх обговорення. Важливими засобами інноваційного забезпечення у сорері охорони здоров'я $є$ МР та ІЛ. Методичні рекомендації містять повний опис інноваційної технології, що пропонується для впровадження. Особливістю їх $€$ адресне інфрормування спеціалістів про новітні досягнення медичної науки з прикладної тематики. Це дає можливість забезпечити лікарів практичної охорони здоров'я інформацією про нові медичні технології діагностики, лікування, профрілактики та нові срорми організації управління охорони здоров'я.

Ретроспективний аналіз методичних рекомендацій, які надійшли у 2017 р. до Укрмедпатентінформу, показав, що за даний період було розроблено 103 (83,74 \%) МР установами МОЗ України, $18(14,63 \%)$ МР установами НАМН України, 2 МР $(1,63 \%)$ іншими установами. 
Серед установ МОЗ України найбільше нових розробок, представлених у МР, запропонував Національний фрармацевтичний університет 20 МР, що становило 19,4 \% від загальної кількості МР установ МОЗ України. Друге рангове місце за кількістю МР поділили Вищий державний навчальний заклад України «Українська медична стоматологічна академія» та Державний вищий навчальний заклад «Івано-Франківський національний медичний університет МОЗ України»розроблено по 13 MP (12,62 \%). Третє рангове місце зайняла Національна медична академія післядипломної освіти ім. П. Л. Шупика (11 МР $10,68 \%)$.

Лідерами закількістюукладених МР серед установ НАМН України у 2017 р. були ДУ «нститут герентології ім. Д. Ф. Чеботарьова НАМН України»4 (22,22 \% від загальної кількості МР, розроблених установами НАМН України), ДУ «Інститут педіатрії, акушерства і гінекології НАМН України» -
3 (16,67 \%) та ДУ «Національний інститут терапії імені Л. Т. Малої НАМН України» - 2 (11,11 \%) МР.

У 2017 р. установи-розробники найбільшу увагу приділяли проблемам «Фармакологія. Фармація. Клінічна фрармакологія і клінічна фрармація. Організація і управління фрармацією», «Стоматологія», «Хірургія. Хірургія серця і магістральних судин», «Онкологія» і «Дерматологія та венерологія» (табл. 1).

Інфрормаційний лист $є$ носієм інфрормації про результати наукових досліджень з певної конкретної проблеми, що викладені в лаконічній формі. У МР та ІЛ обов'язково представлені посилання на джерело доказовості [4].

Результати ретроспективного дослідження ІЛ, розроблених науковими установами у 2017 р., показали, що до Укрмедпатентінформу найбільше ІЛ надійшло від установ МОЗ України - 80,95 \% від загальної кількості.

Таблиця 1. Кількість методичних рекомендацій, розроблених науковими установами МОЗ та НАМН України у 2017 р., за різними напрямами

\begin{tabular}{|c|c|c|}
\hline № $3 а / п$ & Медичний напрям & Кількість МР \\
\hline 1 & $\begin{array}{l}\text { Фармакологія. Фармація. Клінічна фрармакологія і клінічна фрармація. Організація } \\
\text { і управління фармацією }\end{array}$ & 27 \\
\hline 2 & Стоматологія & 17 \\
\hline 3 & Хірургія. Хірургія серця і магістральних судин & 11 \\
\hline 4 & Онкологія & 7 \\
\hline 5 & Терапія & 7 \\
\hline 6 & Дерматологія та венерологія & 5 \\
\hline 7 & Акушерство та гінекологія & 4 \\
\hline 8 & Геронтологія та геріатрія & 4 \\
\hline 9 & Організація і управління охороною здоров'я & 4 \\
\hline 10 & Загальна практика - сімейна медицина & 3 \\
\hline 11 & Інфекційні хвороби & 3 \\
\hline 12 & Педіатрія, неонатологія & 3 \\
\hline 13 & Неврологія & 2 \\
\hline 14 & Нейрохірургія & 2 \\
\hline 15 & Ортопедія і травматологія & 2 \\
\hline 16 & Отоларингологія & 2 \\
\hline 17 & Офртальмологія & 2 \\
\hline 18 & Патологічна анатомія & 2 \\
\hline 19 & Психіатрія & 2 \\
\hline 20 & Фізіотерапія та курортологія & 2 \\
\hline 21 & Морфологія людини & 2 \\
\hline 22 & Алергологія & 1 \\
\hline 23 & Медична генетика & 1 \\
\hline 24 & Ендокринологія & 1 \\
\hline 25 & Медицина невідкладних станів & 1 \\
\hline 26 & Медична психологія & 1 \\
\hline 27 & Нормальна та патологічна фрізіологія & 1 \\
\hline 28 & Пульмонологія та фртизіатрія & 1 \\
\hline 29 & Судово-медична експертиза & 1 \\
\hline \multirow[t]{2}{*}{30} & Урологія & 1 \\
\hline & Всього & 123 \\
\hline
\end{tabular}


Левову частку ІЛ, а саме 42,61 \% від загальної кількості та 52,60 \% від ІЛ, укладачами яких були установи МОЗ України, було складено науковцями Харківського національного медичного університету, ВДНЗ України «Українська медична стоматологічна академія», Харківської медичної академії післядипломної освіти, Львівського національного медичного університету ім. Данила Галицького та Д3 «Дніпропетровська медична академія МО3 України» (табл. 2).

Найбільша кількість ІЛ у 2017 р. була присвячена інноваціям за напрямками «Стоматологія» та «Фармація» - 42 та 32 (10,53 \% та 8,02 \% від загальної кількості) відповідно. Основні медичні напрями, за якими розроблено та представлено в ІЛ значну частину інновацій у 2017 р., показано у таблиці 3.

Найменшу кількість ІЛ (1) укладено за такими напрямами: «Вірусологія та мікробіологія», «Геронтологія та геріатрія», «Медична генетика», «Курортологія та фрізіотерапія», «Офртальмологія», «Отоларингологія», «Радіаційна гігієна», «Судова медицина», «Урологія», «Хірургічне лікування серця та судин».

\section{Таблиця 2. Рейтинг найактивніших наукових установ за кількістю укладених Іл}

\begin{tabular}{|c|l|c|c|c|}
\hline $\begin{array}{c}\text { № } \\
\text { за/п }\end{array}$ & \multicolumn{1}{|c|}{ Назва установи } & $\begin{array}{c}\text { Кількість } \\
\text { ІЛ }\end{array}$ & $\begin{array}{l}\text { Питома вага Іл } \\
\text { від їх загальної } \\
\text { кількості (\%) }\end{array}$ & $\begin{array}{c}\text { Питома вага ІЛ від ІЛ, } \\
\text { розроблених } \\
\text { установами } \\
\text { МО3 України (\%) }\end{array}$ \\
\hline 1 & Харківський національний медичний університет & 47 & 11,78 & 14,55 \\
\hline 2 & $\begin{array}{l}\text { Вищий державний навчальний заклад України } \\
\text { «ураїнська медична стоматологічна академія» }\end{array}$ & 44 & 11,03 & 13,62 \\
\hline 3 & $\begin{array}{l}\text { Харківська медична академія післядипломної } \\
\text { освіти }\end{array}$ & 29 & 7,27 & 8,98 \\
\hline 4 & $\begin{array}{l}\text { Львівський національний медичний університет } \\
\text { ім. Данила Галицького }\end{array}$ & 27 & 6,77 & 8,36 \\
\hline 5 & $\begin{array}{l}\text { ДЗ «Дніпропетровська медична академія МОЗ } \\
\text { України» }\end{array}$ & 23 & 5,76 & 7,12 \\
\hline & Всього & 170 & 42,61 & 52,6 \\
\hline
\end{tabular}

Таблиця 3. Медичні напрями, за якими розроблено та представлено в Іл найбільше інновацій у 2017 р.

\begin{tabular}{|c|l|c|}
\hline № 3а/п & \multicolumn{1}{|c|}{ Медичний напрям } & Кількість ІЛ \\
\hline 1 & Стоматологія & 42 \\
\hline 2 & Фармація & 32 \\
\hline 3 & Терапія & 26 \\
\hline 4 & Інфрекційні та паразитарні хвороби & 25 \\
\hline 5 & Гігієна навколишнього середовища & 24 \\
\hline 6 & Педіатрія & 23 \\
\hline 7 & Хірургія & 23 \\
\hline 8 & Акушерство та гінекологія & 21 \\
\hline 9 & Психіатрія та наркологія & 19 \\
\hline
\end{tabular}

Одним із засобів ознайомлення спеціалістів певного профілю з новітніми результатами наукових розробок та медичними технологіями $є$ проведення наукових форумів. 23.06.2017 р. був затверджений спільний наказ Міністерства охорони здоров'я України та Національної академії медичних наук України № 699/41 «Про затвердження Інструкції 3 підготовки та проведення з'їздів, конгресів, симпозіумів та науково-практичних конференцій установами Міністерства охорони здоров'я України та Національної академії медичних наук України» [2].

Інструкція, що затверджена вищевказаним наказом, впорядковує планування, проведення та звітування за проведення наукових медичних фрорумів (далі - НМФ) науково-дослідними установами МОЗ та НАМН України, вищими медичними (фармацевтичним) навчальними закладами, закладами післядипломної освіти МO3 України, закладами охорони здоров'я, що надають високоспеціалізовану медичну допомогу та $є$ клінічними базами науково-дослідних установ та/або вищих медичних (фармацевтичного) навчальних закладів та закладів післядипломної освіти, а також громадськими організаціями (науково-медичними товариствами, асоціаціями та ін.).

Уперше в Інструкції прописано регламент планування, реєстрації, проведення і звітування додаткових НМФ, що за різних обставин не були подані своєчасно до Реєстру з'їздів, конгресів, симпозіумів та науково-практичних конференцій. 
Щорічно в Укрмедпатентінорормі опрацьовуються заявки на проведення НМФ у сфрері охорони здоров'я України з метою формування Реєстру наукових форумів на наступний рік. Щорічний Реєстр наукових фрорумів $є$ головним засобом координації проведення відповідних заходів у сорері охорони здоров'я України. У 2017 р. установиорганізатори прозвітували за проведення 297 НМФ.

\section{Висновки}

Моніторинг основних засобів інноваційного забезпечення у сфері охорони здоров'я України у 2017 р. показав, що установи-розробники найбільшу увагу приділяли проблемам «Фармакологія. Фармація. Клінічна фрармакологія і клінічна фрармація. Організація і управління фрармацією» та «Стоматологія». За вказаний період науковці запропонували найменшу кількість як МР, так IЛ за медичними напрямами «Медична генетика», «Судова медицина» та «Урологія».

Для підвищення рівня здоров'я населення та покращення якості його медичного обслуговування необхідно розробляти більше засобів наукової комунікації 3 подальшим їх впровадженням у практичну діяльність закладів охорони здоров'я. Надання повноцінної, своєчасної та якісної інорормації про досягнення сучасної медицини $€$ першочерговим завданням науковців.

Перспективи подальших досліджень полягають у підвищенні впливу ефективної системи інноваційного забезпечення та впровадженні повноцінної, своєчасної та якісної наукової продукції в практику охорони здоров'я.

\section{Список літератури}

1. Свінціцький А. С. Актуальні питання щодо впровадження медичних інноваційних технологій у закладах охорони здоров'я [Електронний ресурс] / А. С. Свінціцький, О. І. Висоцька // Практикуючий лікар. - 2015. - № 1. - Режим доступу : http//www.likar-praktik.kiev.ua.

2. Про затвердження Інструкції з підготовки та проведення з'їздів, конгресів, симпозіумів та науково-практичних конореренцій установами Міністерства охорони здоров'я України та Національної академії медичних наук України : наказ Міністерства охорони здоров'я України та Національної академії медичних наук України від 23.06.2017 р. № 699/41.

3. Питання підвищення ефективності інноваційної та винахідницької діяльності й розвитку транссреру медичних технологій у сорері охорони здоров'я України / В. В. Лазоришинець, О. П. Волосовець, О. М. Кочет [та ін.] // Український медичний часопис. - 2014. - № 4. - С. 142-145.

4. Порядок підготовки основних засобів наукової комунікації для реалізації інноваційних технологій в медицині від 10.07.06 : метод. рекомендації. - К., 2006. - 23 с.

\section{References}

1. Svintsitskyy, A.S. \& Vysotska, O.I. ([2015). Aktualni pytannia shchodo vprovadzhennia medychnykh innovatsiinykh tekhnolohii u zakladakh okhorony zdorovia [Current issues on the implementation of medical innovative technologies in health care facilities]. Praktykuyuchyi likar - Practicing Doctor, 1. - Retrieved from: http//www.likar-praktik.kiev.ua. [in Ukrainian]. 2. Nakaz Ministerstva okhorony zdorovia Ukrainy ta Natsionalnoi akademii medychnykh nauk Ukrainy vid 23.06.2017 r. № 699/41 "Pro zatverdzhennia Instruktsii z pidhotovky ta provedennia zizdiv, konhresiv, sympoziumiv ta naukovopraktychnykh konferentsii ustanovamy Ministerstva okhorony zdorovia Ukrainy ta Natsionalnoi akademii medychnykh nauk Ukrayiny" [Order of the Ministry of Health of Ukraine and the National Academy of Medical Sciences of Ukraine dated June 23, 2017 No. 699/41 "On Approving the Instructions for the Preparation and Conduct of Conferences, Congresses, Symposiums and Scientific and Practical Conferences by the Institutions of the Ministry of Health" I of Ukraine and the National Academy of Medical Sciences of Ukraine]. - Retrieved from: http://www.ukrmedpatentinform.com.ua/nakazvid-23-06-2017-699-41-pro-zatverdzhennya-instruktsiyi-z-pidgotovki-ta-provedennya-z-yizdiv-kongresiv-simpoziumiv-tanaukovo-praktichnih-konferentsiy-ustanovami-ministerstva-ohoroni-zdo/

3. Lazorishinets, V.V., Volosovets, O. P., Kochet, A.M., Gorban, A.Ye., Zakrutko, L.I. \& Leshchyshina, A.M. (2014). Pytannia pidvyshchennia efektyvnosti innovatsiynoi ta vynakhidnytskoi diyalnosti y rozvytku transferu medychnykh tekhnolohi u sferi okhorony zdorovia Ukrainy [The issue of improving the efficiency of innovative and inventive activity and the development of transfer of medical technologies in the field of health protection of Ukraine]. Ukrayinskyi medychnyi chasopys - Ukrainian Medical Journal, 4, 142-145 [in Ukrainian].

4. (2006). Poriadok pidhotovky osnovnykh zasobiv naukovoi komunikatsii dlia realizatsii innovatsiynykh tekhnolohi $v$ medytsyni vid 10.07.06: metod. Rekomendatsii [Procedure for preparation of basic means of scientific communication for the implementation of innovative technologies in medicine dated 07.10.06: method. recommendations]. Kyiv, 23 [in Ukrainian].

\section{МОНИТОРИНГ ОСНОВНЫХ СРЕДСТВ ИННОВАЦИОННОГО ОБЕСПЕЧЕНИЯ В СФЕРЕ ЗДРАВО- ОХРАНЕНИЯ УКРАИНЫ В 2017 г.}

Л.И. Закрутько, Л.Г. Билан, Л.В. Ильницкая, Л.М. Новгородская, А.В. Мыслицкий

Украинский центр научной медицинской информации и патентно-лицензионной работы МЗ Украины, г. Киев, Украина

Цель: провести мониторинг основных средств инновационного обеспечения в сфере охраны здравоохранения Украины в 2017 г. 
Материалы и методы. Проанализированы основные средства инновационного обеспечения в сфере здравоохранения Украины, разработанные в 2017 г. Использованы методы экспертной оценки, статистического, системного, структурно-логического и кластерного анализа.

Результаты. Ретроспективный анализ основных средств инновационного обеспечения в сфере здравоохранения Украины в 2017 г. показал, что за данный период было разработано наибольшее количество методических рекомендаций и информационных писем учреждениями МЗ Украины - 83,74 \% и 80,95 \% соответственно. Учреждения-разработчики наибольшее внимание уделяли проблемам «Фармакология. Фармация. Клиническая фрармакология и клиническая фармация. Организация и управление фрармацией» и «Стоматология». За указанный период учеными было предложено наименьшее количество как методических рекомендаций, так и иноормационных писем по медицинским направлениям «Медицинская генетика», «Судебная медицина» и «Урология».

Выводы. Для повышения уровня здоровья населения и улучшения качества его медицинского обслуживания необходимо разрабатывать больше средств научной коммуникации с их последующим внедрением в практическую деятельность учреждений здравоохранения.

КЛЮЧЕВЫЕ СЛОВА: мониторинг; здравоохранение; инновационное обеспечение.

MONITORING THE BASIC INNOVATION SUPPLY IN THE HEALTH PROTECTION OF UKRAINE IN 2017 L.I. Zakrutko, L.G. Bilan, L.V. IInitskaya, L.M. Novgorodskaya, O.V. Myslytskyi

Ukrainian Center for Scientific Medical Information and Patent and Licensing of the Ministry of Health of Ukraine, Kyiv, Ukraine

Purpose: to monitor the main means of innovation support in the field of health protection of Ukraine in 2017.

Materials and Methods. The main means of innovative support in the field of health protection of Ukraine, developed in 2017, have been analyzed. The methods of expert evaluation, statistical, systemic, structural-logical and cluster analysis are applied.

Results. A retrospective analysis of the main means of innovative support in the field of health care in Ukraine in 2017 showed that during this period the methodological recommendations and informational letters were the most developed by the institutions of the Ministry of Health of Ukraine $-83.74 \%$ and $80.95 \%$ respectively. Institutionsdevelopers paid the greatest attention to the problems "Pharmacology. Pharmacy. Clinical Pharmacology and Clinical Pharmacy. Organization and Management of Pharmacy" and "Dentistry". During the mentioned period, the scientists had the smallest number of methodological recommendations, as well as information letters on medical directions "Medical genetics", "Trial medicine" and "Urology".

Conclusions. To increase the health of the population and improve the quality of its medical care, it is necessary to develop more means of scientific communication with their further introduction into the practical activities of health facilities.

KEY WORDS: monitoring; health protection; innovation providing.

Рукопис надійшов до редакції 17.04.2018

\section{Відомості про авторів:}

Закрутько Леся Іллівна - кандидат медичних наук, доцент, в.о. директора Українського центру наукової медичної інформації та патентно-ліцензійної роботи МОЗ України; тел.: +38(044) 428-37-22, +38(095) 480-99-34.

Білан Лариса Григорівна- кандидат медичних наук, завідувач відділу Українського центру наукової медичної інформації та патентно-ліцензійної роботи МОЗ України; тел.: +38(044) 428-37-22.

Ільницька л.В. - кандидат фрілософрських наук, провідний науковий співробітник Українського центру наукової медичної інформації та патентно-ліцензійної роботи МОЗ України; тел.: +38(044) 428-37-22.

Новгородська Лідія Михайлівна - старший науковий співробітник Українського центру наукової медичної інфрормації та патентно-ліцензійної роботи МОЗ України; тел.: +38(044) 428-37-22.

Мислицький О.В. - науковий співробітник Українського центру наукової медичної інформації та патентноліцензійної роботи МО3 України; тел.: +38(044) 428-37-22. 